\title{
Pengaruh Bermain Ulartangga Terhadap Gerak Langkah Lurus Siswa Tunagrahita Ringan
}

\author{
Mecca Puspitaningsari'1), Amelia Febriana²), \\ Pendidikan Jasmani, Sekolah Tinggi Keguruan dan IImu Pendidikan PGRI Jombang \\ Email: mecca27.stkipjb@gmail.com
}

\begin{abstract}
Abstrak
Penelitian ini bertujuan untuk mengetahui adanya pengaruh bermain ulartangga terhadap gerak langkah lurus siswa tunagrahita ringan SLB Ngoro. Penelitian ini menggunakan metode penelitian eksperimen Single Subject Research (SSR) atau disebut penelitian subjek tunggal. Sample dalam penelitian ini berjumlah 1 orang karena menggunakan Single Subject Research (SSR).Desain yang digunakan dalam penelitian ini adalah $A-B-A$. Dengan 8 kali pertemuan untuk fasebaseline A1, Intervensi dan fase baseline A2. Hasil penelitian dilihat dari persentase stabilitasnya pada fase baseline A1 $100 \%$ sedangkan pada fase intervensi $B$ hanya $25 \%$ dan baseline A2 adalah $100 \%$. (c) perubahan level juga membaik meskipun sangat sedikit. (d) pada persentase tidak ada data yang overlap yaitu $0 \%$ dan $0 \%$. Persentase overlap ini dikatakan baik karena semakin kecil persentasenya maka semakin baik
\end{abstract}

Kata kunci: bermain, langkah lurus, tunagrahita

\begin{abstract}
This study aims to determine the effect of playing snake and ladder on the straight steps of mild mentally retarded students at SLB Ngoro. This research uses the experimental research method Single Subject Research (SSR) or so-called single subject research. The sample in this study amounted to 1 person because it used Single Subject Research (SSR). The design used in this study was A - B - A. With 8 meetings for the A1 baseline phase, Intervention and A2 baseline phase. The results of the study were seen from the percentage of stability in the baseline phase $A 1$ of $100 \%$ while in the intervention phase B it was only $25 \%$ and the baseline A2 was $100 \%$. (c) the change in level also improved although very slightly. (d) on the percentage there is no overlapping data, namely $0 \%$ and $0 \%$. This overlap percentage is said to be good because the smaller the percentage, the better
\end{abstract}

Keywords : play, straight steps, mental retardation

\section{PENDAHULUAN}

Pendidikan tidak hanya terbatas pada anak normal saja akan tetapi juga pada anakanak luarbiasa. Keluarbiasaan yang dimiliki anak tersebut dapat merupakan sesuatu yang positif, dapat pula yang negatif. Dengan demikian, berada dibawah rata-rata anak normal. Oleh karena itu, jika kita berbicara tentang anak luar biasa maka yang kita maksud bukan hanya anak-anak yang mempunyai kekurangan, tetapi juga anak-anak yang mempunyai kelebihan (I.G.A.K. Wardani, 2014: 40).

Setiap anak membawa keunikan masing-masing, sebagai seorang guru harus lebih kreatif agar tujuan pendidikan jasmani bisa dikuasai siswa. Pencapaian tujuan pendidikan jasmani tidak hanya pada siswa biasa saja akan tetapi siswa luar biasapun memiliki hak yang sama. Bermain merupakan salah satu hal yang membuat siapapun merasakan senang, tanpa ada unsur pemaksaan, sehingga secara naluri akan melaksanakan dengan senang hati, salah satu konsep inilah yang harus guru jadikan pegangan dalam membuat kreatifitas pembelajaran terutama pembelajaran pendidikan jasmani. Permainan merupakan bentuk pembelajaran pendidikan jasmani yang di kemas menjadi suatu permainan yang menyenangkan tetapi tetap memberikan manfaat bagi siswa. Permainan siswa memiliki 
kebebasan untuk mengekspresikan kemampuannya terhadap tujuan pembelajaran yang telah di tetapkan (Arini, 2017).

Salah satu materi pembelajaran dasar pendidikan jasmani yang harus dikuasai siswa tunagrahita ringan adalah aktivitas gerak langkah. Sesuai dengan standar kompetensi melakukan berbagai kombinasi gerak dasar melalui permainan dan nilai-nilai yang terkandung didalamnya, sedangkan kompetensi dasarnya yaitu melakukan gerak dasar melempar, menangkap, dan menendang. Siswa tunagrahita masih bisa melakukan gerakan yang disuruh guru karena siswa tunagrahita tidak memiliki cacat otot atau tulang, akan tetapi berjalan dengan lurus merupakan salah satu hambatan dalam melakukan gerakan dasar motorik. Meskipun dalam penerapan pembelajaran pendidikan jasmani untuk tuna grahita ringan masih membutuhkan waktu yang sedikit lama. Jalan kaki adalah suatu kegiatan fisik yang menggunakan otot-otot terutama otot kaki untuk berpindah dari suatu tempat atau ketempat lain. Gerak tubuh yang kita lakukan dalam berjalan didominasi oleh langkah kaki, meskipun gerak tangan, dan anggota badan lainnya juga diperlukan tetapi gerak langkah kaki sebagai gerak utama (Gumilar, 2016)

Bermain ulartangga merupakan salah satu bentuk permainan yang klasik, akan tetapi sampai sekarangpun permainan ulartangga masih banyak diminati mulai dari anak-anak samapai orang tua, karena dalam permainan ulartangga terdapat 3 unsur perkembangan yaitu kognitif, psikomotor juga afektif sehingga bermain ulartangga banyak dimodifikasi oleh guru sebagai media pembelajaran. Bermain ulartangga yang disesuaikan dengan pembelajaran dan kebutuhan siswa. Bentuk papan ular tangga meskipun sudah dimodifikasi sesuai kebutuhan pembelajaran, akan tetapi cara bermainnya tetap sama dengan menggunakan dadu sebagai pedoman untuk melangkahkan pionnya. Oleh karena itu, peneliti menggunakan bermain ulartangga pembelajaran gerak langkah lurus pada anak tunagrahita ringan di SLB Ngoro Jombang.

\section{METODE}

Penelitian ini menggunakan metode penelitian eksperimen Single Subject Research (SSR) atau disebut penelitian subjek tunggal.(Sukmadinata, 2011) mengatakan, Eksperimen subjek tunggal adalah suatu eksperimen yang subjeknya bersifat tunggal, bisa 1 orang, 2 orang atau lebih. Namun subjek tunggal juga diambil dari cara hasil eksperimen yang disajikan dan dianalisis berdasarkan subjek secara individual. Pendekatan dasar dalam eksperimen subjek tunggal adalah meneliti individu dalam kondisi tanpa perlakuan dan kemudian dengan perlakuan dan akibatnya terhadap variabel yang diukur dalam kedua kondisi tersebut.

Desain yang digunakan dalam penelitian ini adalah A - B - A. (Sunanto, Takeuchi, \& Nakata, 2005) berpendapat bahwa, Desain A-B-A merupakan salah satu pengembangan dari desain $A-B$, desain A-B-A ini telah menunjukkan adanya hubungan sebab akibat antara variable terikat dan variable bebas. Prosedur dasarnya tidak begitu berbeda dengan desain A$B$, tetapi hanya ada pengulangan fase baseline. Mula-mula target behavior diukur secara continue pada kondisi baseline (A1) dengan periode waktu tertentu kemudian pada kondisi intervensi (B). berbeda dengan desain $A-B$, pada desain $A-B-A$ setelah mengukur pada kondisi intervensi (B) pengukuran pada kondisi baseline kedua (A2) diberikan. Penambahan kondisi baseline kedua (A2) ini dimaksud sebagai control untuk fase interfensi sehingga memungkinkan untuk menarik kesimpulan adanya hubungan fungsional antara variable terikat dan variable bebas.

Untuk mendapatkan validitas penelitian yang baik, pada saat melakukan eksperimen dengan desain A-B-A, peneliti perlu memperhatikan beberapa hal berikut ini.

- Mendefinisikan target behavior sebagai perilaku yang dapat diukur secara akurat

- Mengukur dan mengumpulkan data pada kondisi baseline (A1) secara kontinyu sekurang-kurangnya 3 atau 5 atau sampai trend dan level data menjadi stabil

- Mengukur dan mengumpulkan data pada fase intervensi (B) dengan periode waktu tertentu sampai data menjadi stabil

- Setelah kecenderungan dan level data pada fase intervensi (B) stabil mengulang fase baseline (A2) 


\begin{tabular}{|c|c|c|}
\hline Baseline 1 & Treatment & Baseline 2 \\
O 0 0 0 & $\begin{array}{c}\text { x X X X X X } \\
\text { O O O O O }\end{array}$ & O O O \\
0 & & \\
\hline
\end{tabular}

\section{Gambar 3.1 penelitian Single Subjek Reseach (SSR) desain A-B-A.}

\section{HASIL DAN PEMBAHASAN}

Pada kegiatan pra siklus, dilaksanakan tindakan berupa pembelajaran yang menggunakan metode demonstrasi. Kegiatan pra siklus ini dilakukan untuk mengetahui hasil belajar, aktifitas guru, dan aktifitas siswa sebelum dilakukan tindakan pembelajaran menggunakan metode Teaching Games for Understanding (TGfU). Dari pelaksanaan tindakan pra siklus, hasil belajar siswa menunjukkan dari 32 siswa, terdapat 11 siswa yang nilainya diatas kriteria ketuntasan minimal. Selain itu, pada kegiatan pra siklus prosentase aktifitas guru dalam mengajar sebesar $59,37 \%$, dan prosentase aktifitas siswa dalam pembelajaran sebesar $53,12 \%$.

Pada siklus I dilaksanakan tindakan berupa pembelajaran passing bawah individu dan berpasangan. Pembelajaran ini bertujuan untuk pemahaman siswa tentang keterampilan passing bawah yang benar. Dari pelaksanaan tindakan yang telah dilakukan pada siklus I, tingkat kemampuan siswa menunjukkan dari 32 siswa, terdapat 23 siswa yang nilainya diatas kriteria ketuntasan minimal. Selain itu, pada kegiatan siklus I prosentase aktifitas guru dalam mengajar sebesar $72 \%$, dan prosentase aktifitas siswa dalam pembelajaran sebesar $68,75 \%$. Pada kegiatan siklus I, aktifitas guru dan siswa sudah mengalami peningkatan namun belum mencapai target yang diinginkan peneliti. Hal ini dikarenakan masih terdapat hambatanhambatan yang ada pada siklus I.

Pada siklus ke II adalah perbaikan dari siklus pertama, pada siklus ini ada sedikit perubahan pada tindakan, peneliti menambahkan sebuah permainan passing bawah berkelompok. Permainan ini bertujuan untuk meningkatkan keterampilan passing bawah siswa dan keaktifan siswa dalam mengikuti pembelajaran. Dari pelaksanaan tindakan siklus II, peningkatan keterampilan dari 32 siswa, terdapat 28 siswa yang nilainya diatas kriteria ketuntasan minimal. Selain itu, pada kegiatan siklus II, prosentase aktifitas guru dalam mengajar sebesar $87,50 \%$, dan prosentase aktifitas siswa dalam pembelajaran sebesar $84,37 \%$. Hal ini sejalan dengan adanya perubahan perilaku siswa yang menunjukkan keaktifan dalam mengikuti proses pembelajaran dengan baik.

Berikut diagram hasil ketuntasan pembelajaran passing bawah bolavoli siswa kelas VIII B SMP Negeri 1 Tembelang Jombang tahun pelajaran 2019/2020 mulai dari pra-siklus hingga ke siklus II.

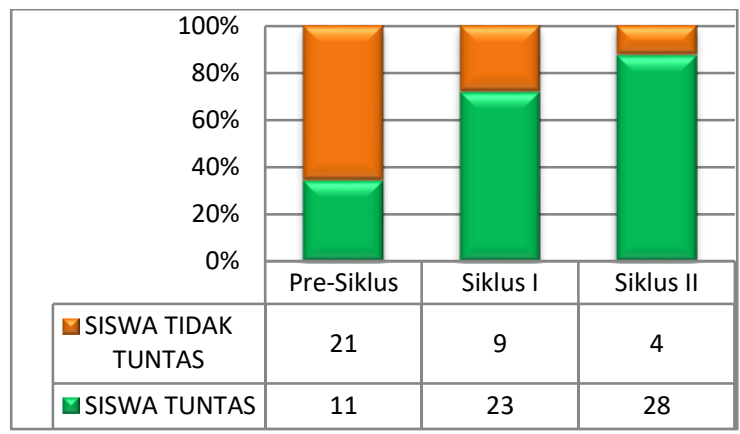

Gambar 4.4 Grafik Ketuntasan Belajar Siswa 


\section{SIMPULAN}

Simpulan dari analisis antar kondisi dari sebagai berikut : (a) perubahan kecenderungan arah pada subjek menuju perubahan yang positif sebab dapat dilihat pada grafik. (b) perubahan kecenderungan stabilitas pada baseline A1 stabil sedangkan pada intervensi B tidak stabil atau variabel dan baseline A2 cenderung stabil. Dapat dilihat dari persentase stabilitasnya pada fase baseline A1 100\% sedangkan pada fase intervensi B hanya $25 \%$ dan baseline A2 adalah $100 \%$. (c) perubahan level juga membaik meskipun sangat sedikit. (d) pada persentase tidak ada data yang overlap yaitu $0 \%$ dan $0 \%$. Persentase overlap ini dikatakan baik karena semakin kecil persentasenya maka semakin baik.

\section{UCAPAN TERIMA KASIH}

Peneliti ucapkan terima kasih sebesar-besarnya kepada lembaga STKIP PGRI Jombang atas kontribusinya yang telah membantu dengan memberikan bantuan dana demi terselesaikannya penelitian ini. Semoga STKIP PGRI Jombang semakin bertambah maju dan mampu turut andil dalam mencerdaskan perkembangan di kabupaten Jombang dan dunia pada umumnya dalam dunia pendidikan. Peneliti juga mengucapkan terimakasih kepada Kepala Sekolah SLB Ngoro.

\section{DAFTAR PUSTAKA}

Arikunto, S. (2010). Prosedur Penelitian Suatu Pendekatan Praktik. Jakarta: PT Rineka Cipta. Arini, R. R. (2017). Pengaruh Permainan Tradisional Terhadap Kebugaran Jasmani Pada Siswa Kelas X Madrasah Aliyah Negeri Jombang Tahun Pelajaran 2017/2018. Skripsi. Gumilar. (2016). Keterampilan Gerak Aktivitas Jalan, Lari, Lompat, Lempar. 57-126

I.G.A.K. Wardani, D. (2014). Pengantar Pemdidikan Anak Berkebutuhan Khusus (1st ed.). Tangerang Selatan.

JUNAEDI, A. (2016). Survei Tingkat Kemajuan Pendidikan Jasmani, Olahraga, Dan Kesehatan Di Sma, Smk, Dan Ma Negeri Se-Kabupaten Gresik. Jurnal Pendidikan Olahraga Dan Kesehatan, 3(3), 834-842.

Mulyani, E. T. (2019). PENGARUH PERMAINAN ENGKLEK TERHADAP MOTORIK. 2(2), 49-58.

Ratnaningsih, N. N. (2014). Penggunaan Permainan Ular Tangga Untuk Meningkatkan Motivasi Belajar IPS Kelas III A SDN Nogopuro Sleman. Skripsi.

Sugiyono. (2016). Metode Penelitian dan Pengembangan Reseach and Development (2nd ed.; S. Y. Suryandari, ed.). Bandung: Alfabeta.

Sugiyono. (2016). Metode Penelitian dan Pengembangan Reseach and Development (2nd ed.; S. Y. Suryandari, ed.). Bandung: Alfabeta.

Sukmadinata, N. S. (2011). Metode Penelitian Pendidikan (7th ed.). Bandung: PT Remaja Rosdakarya Offset.

Sunanto, J., Takeuchi, K., \& Nakata, H. (2005). Pengantar Penelitian Dengan Subyek Tunggal. 